\title{
Stalin och det svenska i Finland
}

\author{
Kommunistisk nationalitetsteori och den tidiga finlandssvenska \\ folkdemokratin
}

Det ÄR INTE OVANLIGT ATt finlandssvenskarnas ställning under I90o-talet förbinds med den liberala och borgerliga demokratins fortlevnad i Finland. Henrik Meinander menar att den svenskspråkiga befolkningen skulle ha drabbats av en "total kollaps" om fortsättningskriget slutat i "ett kommunistiskt Finland". Enligt Meinander skulle ett kommunistiskt maktövertagande ha medfört att finlandssvenskarnas "lagstadgade rättigheter antingen hade slopats eller mist sin betydelse", samt att de flesta finlandssvenska institutioner demonterats. ${ }^{1}$ Meinanders kontrafaktiska hypotes anger onekligen en möjlig utveckling, särskilt ifall Finland ockuperats av Röda armén. En idéhistorisk analys av kommunismens nationalitetsteori och -politik kan dock ge oss en annan och väsensskild bild av finlandssvenskarnas framtid i ett kommunistiskt efterkrigstida Finland. Enligt detta scenario kunde den av folkdemokraterna eftersträvade demokratiseringen ${ }^{2}$ av Finland lett till att finlandssvenskarnas rättigheter och institutioner omformulerats och deras intuitioner omstrukturerats $i$ den nya socialistiska folkrepubliken. Införandet av ett socialistiskt samhällssystem kunde ha resulterat i nya minoritetsnationella organ och enheter, exempelvis en finlandssvensk autonom region på samma sätt som förvaltningsområden inrättades för nationella minoriteter i

I. Henrik Meinander, Nationalstaten: Finlands svenskhet 1922-2015, Helsingfors: Svenska litteratursällskapet i Finland 20I6, s. I30.

2. Enligt den kommunistiska idétraditionen är arbetarklassens (majoritetens) herravälde över samhället, proletariatets diktatur, mer demokratisk än borgarklassens (minoritetens), men fullständig demokrati uppnås först i det klass- och statslösa kommunistiska samhället. 
de östeuropeiska folkrepublikerna. Dessa kunde, åtminstone i princip, ha garanterat finlandssvenskarnas rättigheter under ledning av finlandssvenska kommunister.

Syftet med uppsatsen är att idéhistoriskt belysa den kommunistiska nationalitetsteorin i allmänhet och särskilt dess betydelse för de finlandssvenska folkdemokraterna och kommunisterna under de första efterkrigsåren. Källmaterialet utgörs av Demokratiska förbundet för Finlands folks och Finlands kommunistiska partis material rörande den svenskspråkiga minoriteten i Finland, tillsammans med relevant kommunistisk (bolsjevikisk) teorilitteratur, framför allt Stalins Marxismen och den nationella frågan. Den övergripande frågan för uppsatsen är hur de finländska kommunisterna och folkdemokraterna, särskilt de finlandssvenska, begreppsliggjorde och politiserade den svenskspråkiga minoritetens ställning i Finland fram till Finlands kommunistiska partis organisationsreform år 1951. Den kommunistiska nationalitetsteorins tillämpning på finlandssvenskarna har hittills inte varit föremål för historievetenskapliga undersökningar. Uppsatsen lämnar därmed bidrag till såväl den transnationella finländska kommunismens historia som forskningen om den finlandssvenska yttervänsterns historia i Finland.

\section{DEN FINLANDSSVENSKA FOLKDEMOKRATIN}

Demokratiska förbundet för Finlands folk (DFFF) grundades i slutet av oktober 1944 av vänstersocialdemokrater och Finlands kommunistiska parti (FKP), som efter vapenstilleståndsavtalet mellan Finland och Sovjetunionen hösten 1944 kunde göra entré i landets politiska liv. DFFF skulle enligt kommunisternas planer fungera som en samlande front- och valorganisation. Syftet var att locka en bredare vänsterradikal väljargrupp än vad FKP ensamt kunde dra till sig och därigenom bereda kommunisternas väg till makten. De socialister som anslöt sig till DFFF dansade dock inte alltid efter FKP:s pipa utan hade egna visioner för DFFF:s identitet och politik, vilket ledde till slitningar inom både DFFF och FKP. ${ }^{3}$ DFFF skördade stora framgångar i sitt

3. Se exempelvis Erkki Tuomioja, K.H. Wiik: Puoluesibteeri ja oppositiososialisti. Elämäkerta I9I8-I946, Helsinki: Tammi 1982; Atos Wirtanen, Mot mörka makter, 
första (och mest framgångsrika) riksdagsval år 1945 med 23,5 procent av rösterna och blev statsministerparti 1946. I riksdagsvalet år 1948 gick DFFF tillbaka och erhöll därefter valresultat på omkring 20 procent fram till mitten av I970-talet, varefter väljarstödet sjönk kraftigt fram till upplösningen år 1990.

DFFF upprätthöll egna tidningar, ett eget förlag, egna tryckerier samt en rad andra folkdemokratiska institutioner och organisationer. Det grundades även nya svenska folkdemokratiska föreningar och flera äldre svenska arbetarföreningar lämnade Finlands Svenska Arbetarförbund (FSA) för DFFF under de första efterkrigsåren. Svenska sektioner etablerades både inom FKP och DFFF, och svenska sekreterare tillsattes för att samordna och kontrollera såväl det kommunistiska som det folkdemokratiska arbetet på svenska i Finland. Mot slutet av 1940-talet hade en omfattande svenskspråkig verksamhet etablerats i Svenskfinland. De finlandssvenska folkdemokraterna gav dessutom ut en egen tidning, Folktidningen Ny Tid.Tillsammans med FSA grundade de finlandssvenska folkdemokraterna år 1946 en bildningsorganisation, Folkets Bildningsförbund, som de självständigt kontrollerade efter socialdemokraternas utträde år $1949{ }^{4}$

Nationalitetsfrågan var ideologiskt och strategiskt viktig för de finlandssvenska kommunisterna och folkdemokraterna. ${ }^{5}$ Det socialistiska finländska samhälle de arbetade för skulle befria den arbetande finlandssvenska majoriteten från kapitalistisk exploatering och borgerligt förtryck. Det förtryck som riktades mot de finlandssvenska arbetarna ansågs dessutom vara grövre, eftersom den arbetarupplysning som bedrivits bland den finskspråkiga arbetarbefolkningen mera sällan nådde svenskspråkiga arbetare. Alldeles centralt för de finlandssvenska kommunisterna och folkdemokraterna var även att arbetarna skulle delta i klasskampen utan att göra avkall på sin finlandssvenskhet. I själva verket skulle övergången till socialism förstärka den finlands-

Helsingfors: Söderströms I963; Veli-Pekka Leppänen, Kivääri vai äänestyslippu? Suomen kommunistisen puolueen hajaannus 1964-1970, Helsinki: Edita 1999.

4. Mats Wickström \& Jonas Ahlskog, "Socialt och kulturellt vakna medborgare. Socialistisk finlandssvensk folkbildning från samarbete till splittring i Folkets Bildningsförbund r.f., I945-1949", Historisk Tidskrift för Finland Io2, 2017:2, s. 255-285.

5. Alla medlemmar i FKP var samtidigt folkdemokrater, men de flesta folkdemokrater var inte kommunister. 
svenska nationalitetens livsvillkor och trygga dess framtid i Finland. Den här folkdemokratiska framtidsvisionen för finlandssvenskarna var, som vi kommer att visa, förankrad i marxistisk-leninistisk teori, särskilt Josef Stalins i särklass främsta bidrag till detta teoribygge före den ryska revolutionen, Marxismen och den nationella frågan (I9I3). ${ }^{6}$

De finlandssvenska folkdemokraterna verkade inom ett politiskt fält som var minoritetsnationellt konstituerat, Svenskfinland, i konkurrens med en aktör som var sammanflätad med själva fältet (Svenska folkpartiet) och en annan som också gjorde anspråk på att vara socialistisk och svensk (Finlands Svenska Arbetarförbund). Därför var det av största strategiska vikt för folkdemokraterna att utarbeta och förmedla en unik minoritetsnationell ståndpunkt till det finlandssvenska folket som man ansåg vara förtryckt. Samtidigt ansåg ledande finlandssvenska folkdemokrater att förutsättningen för att DFFF skulle skörda framgångar hos den finlandssvenska väljarkåren var en politik som även i sitt försvar av svenskheten i Finland var övertygande. Den aviserade demokratiseringen av Finland, det vill säga inrättandet av ett socialistiskt samhällssystem under kommunistiskt styre, skulle därför förenas med en frigörelse av den finlandssvenska minoriteten. Denna frigörelse inkluderade etnisk emancipation och ett löfte att finlandssvenskheten inte bara skulle fortbestå utan också frodas i det folkdemokratiska Finland. Fram till år 1956 var det också möjligt att hänvisa till absolut högsta ort, nämligen Kreml och Stalins egen nationalitetsteori, för att ge stöd för teserna om finlandssvenskarnas lysande framtid i ett från kapitalism och fascism befriat Finland.

\section{STALINS TEORI OM NATIONEN OCH DEN FINLANDS- SVENSKA FOLKDEMOKRATIN}

Fram till Chrusjtjovs så kallade hemliga tal om personkulten kring Stalin och dess förkastliga följder vid Sovjetunionens Kommunistiska Partis 20:e kongress år 1956, var Stalin en oantastlig ideologisk auktoritet inom såväl finländsk folkdemokrati som världskommunismen. ${ }^{7}$

6. Theodore R. Weeks, "Separatist Nationalism in the Romanov and Soviet Empires", John Breuilly (ed.), The Oxford Handbook of the History of Nationalism, Oxford: Oxford University Press 20I3, s. 207.

7. Bernard S. Morris, Authority and Control in International Communism: 19I7-1967, 
Stalins specialitet som marxistisk teoretiker var nationalitetsfrågan, i vilken han gjorde sig ett namn år I9I3 med en av sina viktigaste skrifter, Marxismen och den nationella frägan, ursprungligen publicerad under titeln Den nationella frägan och socialdemokratin i nummer 3-5 av den bolsjevikiska tidskriften Prosvesjtjenie ("Upplysning"). ${ }^{8}$ Efter oktoberrevolutionen I9I7 utsågs Stalin till folkkommissarie för nationalitetsfrågor i den första sovjetregeringen, en post han innehade fram till år 1923. Redan innan han gick segrande ur maktkampen efter Lenins död år I924 var Stalin, både i sina egna och i andras ögon, en specialist på nationalitetsfrågor. ${ }^{9}$

Stalin skrev Marxismen och den nationella frägan i första hand som en anklagelseskrift mot den österrikiske socialdemokraten Otto Bauer. Bauer var en ledande austromarxistisk ideolog och socialdemokratisk politiker vars första verk Die Nationalitätenfrage und die Sozialdemokratie (1907) gav honom en framträdande position som teoretiker i den internationella arbetarrörelsen. ${ }^{10}$ I Stalins sikte fanns förutom den österrikiska socialdemokratin och dess enligt honom felaktiga nationella program också det första judiska socialdemokratiska partiet Bund (Algemeyner Yidisher Arbeter Bund in Litah, Poyln un Rusland, grundat år 1897). Detta partis förening av socialism och judisk minoritetsnationalism (bundism) tog starkt intryck av austromarxismens idé om nationell kulturautonomi som icke-territoriell förvaltningsprincip för en mångnationell demokratisk stat. ${ }^{11}$

Enligt Stalin vilade en kulturautonom politik på en felaktig teoretisk grund. Det allvarligaste felslutet var att idén om kulturautonomi förandligade nationsbegreppet genom att, på ett sätt som enligt Stalin var omarxistiskt, skilja mellan ett folks nationalkaraktär och de mate-

Abingdon (UK) \& New York: Routledge 2017.

8. Erik van Ree, The Political Thought of Joseph Stalin: A Study in Twentieth Century Revolutionary Patriotism, London: RoutledgeCurzon 2002, s. 64; Josef Stalin, Marxismen och den nationella frågan, Stockholm: Förlag för litteratur på främmande språk I950, s. 97, not I.

9. Timothy Snyder, Sketches from a Secret War: A Polish Artist's Mission to Liberate Soviet Ukraine, New Haven: Yale University Press 2005, s. 35.

Io. Michael Forman, Nationalism and the International Labor Movement: The Idea of the Nation in Socialist and Anarchist Theory, University Park: The Pennsylvania State University Press I998, s. 95-96.

II. Hélène Carrère d'Encausse, The Great Challenge: Nationalities and the Bolsherik State, I9I7-I930, New York: Holmes \& Meier Publishers I992, s. 28. 
riella villkoren för deras liv. Det som Bauer kallade nationalkaraktär var för Stalin endast "en återspegling av levnadsförhållandena, en koncentration av intrycken från den omgivande miljön". ${ }^{12}$ Enligt Stalin var jorden, territoriet, nationens grundval och följaktligen även utgångspunkten för marxistisk nationalitetspolitik: "Hur kan man [som Bauer] inskränka det hela bara till nationalkaraktären och avsöndra och skilja den från den jordmån, som alstrat densamma?"13 Stalin anklagade Bauer för mystifikation och anförde judarna som exempel på hur den Bauerska grundprincipen om nationalkaraktärer inte överensstämde med den materiella och politiska verkligheten:

Bauers ståndpunkt, enligt vilken nationen identifieras med nationalkaraktären, lösrycker nationen från dess grund och förvandlar den till något slags osynlig, självtillräcklig kraft. Resultatet blir inte en levande och verkande nation, utan någonting mystiskt, ogripbart och övernaturligt. Ty, upprepar jag, vad är det exempelvis för en judisk nation, som består av grusiska, dagestanska, ryska, amerikanska och andra judar, vars medlemmar inte förstår varandra (de talar olika språk), lever i olika världsdelar, aldrig kommer att träffas, aldrig kommer att handla gemensamt, vare sig i fred eller i krig?! ${ }^{14}$

Bauer hade enligt Stalin missförstått vad en nation egentligen var. För att rätta till denna såväl ovetenskapliga som politiskt ödesdigra vanföreställning ställde Stalin upp sin egen definition på en nation, en begreppsbestämning som över tre decennier senare skulle spela en stor ideologisk roll för den finlandssvenska folkdemokratin:

En nation är en historiskt uppkommen, varaktig gemenskap mellan människor, som uppstått på grundval av gemenskap ifråga om språket, territoriet, det ekonomiska livet och den mentalitet, som kommer till uttryck $i$ den gemensamma kulturen. Härvid är det självklart att en nation, såväl som varje annan historisk företeelse, är underkastad förändringens lag, äger sin historia, sin början och sitt slut. Det måste betonas att inget av de anförda kännetecknen ensamt för sig är tillräckligt för att definiera

I2. Stalin, Marxismen och den nationella frågan, s. I8.

I3. Ibid.

I4. Ibid., s. I9. 
en nation. Än mer: det behövs bara att ett av dessa kännetecken saknas, för att nationen skall upphöra att vara en nation. ${ }^{15}$

Även om Stalin jämställde de fyra kriterierna (gemensamt språk, territorium, ekonomiskt liv och gemensam mentalitet) för vad som konstituerade en nation, utgjordes den nationella grunden, enligt Stalin, framför allt av de "breda och stabila skikt som är bundna vid torvan" och "på ett naturligt sätt" håller ihop nationen, det vill säga en bofast bondebefolkning. Därför kunde inte de ryska judarna, varav endast tre till fyra procent var verksamma inom lantbruket enligt Stalin, betraktas som en nation utan måste ses som "inströdda" minoriteter i "främmande nationer", där de var på väg att assimileras. ${ }^{16}$ En dylik grupp saknade alltså både de stalinistiska förutsättningarna för ett nationellt liv och en framtid som minoritetsgrupp överhuvudtaget.

Tio år tidigare hade Ryska socialdemokratiska arbetarpartiet, innan splittringen i bolsjeviker och mensjeviker, fattat beslut om att ta in nationell självbestämmanderätt i partiprogrammet. ${ }^{17}$ Frågan hade en mycket djup resonansbotten inom marxistisk tanketradition; om konflikten mellan irländska och engelska arbetare hade Marx själv slagit fast att varje nation som förtrycker en annan smider sina egna bojor. ${ }^{18}$ Andemeningen var att bourgeoisiens hegemoni i respektive nation skulle stärkas då arbetarna från olika nationer hetsades mot varandra. Med andra ord spelade frågan om nationernas självbestämmande en alldeles avgörande roll i den kommunistiska världsrevolutionen, även om Marx, och framför allt Engels, drog en skarp gräns mellan progressiva historiska nationer och reaktionära historielösa folk; endast de tidigare hade förutsättningarna för och rätten till suveränitet. ${ }^{19}$ Rätten till nationellt självbestämmande förblev en del

I5. Ibid. I kursiv i originalet.

I6. Stalin, Marxismen och den nationella frågan, s. 56.

17. "Programme of the Social-Democratic Workers' Party adopted at the Second Congress of the Party", https:/www.marxists.org/history/international/social-democracy/rsdlp/I903/program.htm (hämtad 26/Io 20I7).

I8. Karl Marx i ett sedermera berömt konfidentiellt uttalande i87o till tyska socialistiska ledare om det brittiska styret i Irland. Se Ian Fraser \& Lawrence Wilde, The Marx Dictionary, New York: Continuum 20II, s. I47.

19. Walker Connor, The National Question in Marxist-Leninist Theory and Strategy, Princeton: Princeton University Press I984, s. I2. 
av programmet hos både bolsjevikerna och mensjevikerna, och år I9I4 gav Lenin ut verket Om nationernas självbestämmanderätt i vilket han polemiserade mot Rosa Luxemburgs antinationalistiska ståndpunkt. ${ }^{20}$ För den praktiska politiken utgjorde Stalins fyra nationalitetsvillkor en leninistisk-stalinistisk riktlinje för vilka grupper som överhuvudtaget kunde göra anspråk på att utgöra en nation med därtill hörande rätt till självbestämmande.

På problemet vad"man skall göra med de [minoritets]nationer som av en eller annan anledning föredrar att stanna inom det helas [en demokratiserad stats] ram?"21, en fråga som skulle komma att gälla finlandssvenskarna, hade Stalin en entydig lösning. I en stat "med fullständig demokrati”22 fanns det inte längre något behov vare sig för statens majoritetsnation att förtrycka nationella minoriteter (det vill säga minoritetsgrupper som bildade en nation i enlighet med de fyra villkoren) eller för de nationella minoriteterna att bilda kulturautonoma förbund över statsgränserna eftersom deras krav skulle uppfyllas:

Minoriteten är inte missnöjd över att det inte finns något nationellt förbund, utan för att den är berövad rätten till modersmålet. Ge den rätt att använda sitt modersmål - och missnöjet skall försvinna av sig själv. Minoriteten är inte missnöjd över att det inte finnes ett konstlat förbund, utan över att den inte har en egen nationell skola. Ge den en sådan skola - och missnöjet skall förlora varje jordmån. Minoriteten är inte missnöjd över att det inte finnes ett nationellt förbund, utan för att den är berövad samvetsfrihet (religionsfrihet), flyttningsfrihet o.s.v. Ge den dessa friheter - och den kommer inte längre att vara missnöjd. Således är nationellt likaberättigande $i$ alla dess former (språk, skolor o.s.v.) en oundgänglig punkt vid den nationella frågans lösning. En för hela staten gällande lag är således nödvändig, en lag som är utfärdad på grundval av landets fullständiga demokratisering och som undantagslöst förbjuder alla former av nationella privilegier och varje intrång på eller inskränkning av de nationella minoriteternas rättigheter. ${ }^{23}$

20. Vladimir Iljitj Lenin, Om nationernas självbestämmanderätt, Stockholm: Förlag för litteratur på främmande språk 1955 .

2I. Stalin, Marxismen och den nationella frågan, s. 86 .

22. Ibid., s. 88 .

23. Ibid., s. 88-89. Kursiv i originalet. 
Bolsjevikernas tes om nationernas självbestämmande legitimerade bland annat deras erkännande av Finlands självständighet den $3 \mathrm{I}$ december $1917^{24}$, och den bolsjevikiska lösningen på den nationella frågan blev praktisk politik i Sovjetunionen, som formellt var en federation. Enligt den rysk-amerikanska historikern Yuri Slezkine var den första femårsplansperioden (1928-1932) i Sovjetunionen "the most extravagant celebration of ethnic diversity that any state had ever financed". ${ }^{25}$ Fram till år 1936 hade alla nationaliteter, i princip, rätt till utträde ur staten. ${ }^{26}$ Nationer erkändes på både personlig och territoriell basis, trots att det förra kunde tolkas som ett uttryck för austromarxistisk kulturautonomi. ${ }^{27}$ Alla Sovjetunionens medborgare tilldelades en medfödd personlig nationalitetsmarkör som registrerades i deras pass. Nationer institutionaliserades etno-territoriellt genom att tilldelas nationella områden enligt en hierarkisk ordning. ${ }^{28}$

Finlands kommunistiska parti grundades i Moskva den 29 augusti I9I8 och hade från bildandet fram till år 1944 två hemländer, Sovjetunionen och Finland. Partiets viktiga möten hölls i Sovjetunionen och dess linjedragningar gjordes där efter sovjetisk modell, vilket inte var särskilt ändamålsenligt för verksamheten i ett land där partiet fortfarande strävade efter makten. ${ }^{29}$ För Finlands svenskspråkiga befolkning betydde det att det sovjetiskt renläriga FKP under mellankrigstiden intog en entydig ståndpunkt för finlandssvenskt självbestämmande:

On rohkeasti ja johdonmukaisesti kannatettava ruotsalaisen väestön pisimmällekin tähtääviä autonomisia pyrintöjä ja ahvenanmaalaisten täydellistä riippumattomuutta, eroamista Suomen valtionyhteydestä. On ymmärrettävä että kansallisuuskysymyksen pohjana on talon-

24. Till undertecknarna av Ryska folkkommissariernas råds erkännande av Finlands självständighet hörde förutom Lenin även Stalin och Trotskij.

25. Yuri Slezkine, "The USSR as a Communal Apartment, or How a Socialist State Promoted Ethnic Particularism”, Slavic Review 53, I994:2, s. 4I4.

26. van Ree, The Political Thought of Joseph Stalin, s. I92.

27. Enligt den austromarxistiska personlighetsprincipen bildas en nation av personer som delar nationalkaraktär, oberoende av var de befinner sig.

28. Rogers Brubaker, Nationalism Reframed: Nationhood and the National Question in the New Europe, Cambridge: Cambridge University Press 1996, s. 30-3I.

29. Tauno Saarela,"Suomalainen kommunismi ja rajat", Matti Hannikainen (toim.), Työväestön rajat, Tampere: Työväen historian ja perinteen tutkimuksen seura 2005, s. II6-II7. 
poikaiskysymys, ja niin myös ruotsalaisten kansallisuusliikkeen pääkannattajina talonpoikais- ja kalastajajoukot. Näiden tietoisuuteen on saatava, että Suomen kommunistit horjumattomasti puoltavat ei vain sanoissa, vaan teoissa heidän kansallista itsemääräämisoikeutta aina valtiolliseen eroamiseen saakka. ${ }^{30}$

Bondefrågan som bas för nationalitetsfrågan följde ett av Stalins centrala postulat i Marxismen och den nationella frågan, att nationer var förankrade i jord och dem som brukade den. De finlandssvenska bönderna och fiskarna var nationellt sinnade och understödde därför den borgerliga svenska samlingsrörelsen, det vill säga partipolitiskt sett Svenska folkpartiet (SFP), i tron att endast det kunde bevaka deras nationella intressen. Till skillnad från SFP, som vid mitten av 1920-talet avskrivit finlandssvensk självstyrelse på etnoterritoriell basis från dagordningen ${ }^{31}$, propagerade de finländska kommunisterna för att svenskarna i Finland inte endast hade rätt till territoriell autonomi inom ramen för den finska staten utan även rätt att helt utträda ur denna stat. Genom att överflygla SFP i partiets kärnfråga, "tryggande av dess [Finlands svenska befolknings] framtida utveckling såsom en egen nationalitet" enligt 1924 års partiprogram, eftersträvade FKP att göra ett genombrott bland finlandssvenskarna. ${ }^{32}$ Om finlandssvenskarna verkligen blev nationellt självbestämmande skulle även deras möjligheter till demokratisering öka tack vare en klassbestämd normalisering av de politiska förhållandena inom grup-

30. "Man måste modigt och konsekvent understödja även de mest långtgående autonoma strävandena hos den svenska befolkningen och ålänningarnas fullständiga oavhängighet, deras önskan att skilja sig från den finska statsgemenskapen. Man måste förstå att bondefrågan ligger som grund för den nationella frågan och att allmogen och fiskarna är de som huvudsakligen understöder den svenska nationalitetsrörelsen. Dessa bör göras medvetna om att Finlands kommunister orubbligt förespråkar inte bara i ord utan också i handling deras nationella självbestämmanderätt så långt som till ett utträde ur staten." [Svensk översättning: MJ \& MW]. "SKP:n V Puoluekokous v. I925", Suomen Kommunistinen Puolue: Puoluekokousten, konferenssien ja Keskuskomitean plenumien päätöksiä. Ensimmäinen kokoelma, Leningrad: Valtion Kustannusliike Kirja 1935, s. 96. Se även s. 20I-202, 26I-262 och 36r i samma verk.

31. Meinander, Nationalstaten, s. I7-I8.

32. Svenska folkpartiet, Svenska Folkpartiets program (I924), http://www.fsd.uta.fi/ pohtiva/ohjelmalistat/SFP/564 (hämtad 26/IO 20I7). 
pen. Med regional autonomi flyttades, enligt Stalins teori, arbetarnas fokus från strider mellan nationer till den egna klasskampen inom nationen. ${ }^{33}$ Den finlandssvenska borgerligheten skulle i ett autonomt eller självständigt Svenskfinland förlora sin spårbundna ställning som den svenska nationalitetens självklara försvarare gentemot den finska majoritetsnationalismen (äktfinskheten) och gruppens reella klassförhållanden skulle göra sig gällande till arbetarklassens fördel.

\section{Otto Wille KuUsinens Stalinistiska försvar aV DET SVENSKA I FINLAND}

I maj 1935 publicerade den rikssvenska, kommunistiska dagstidningen $N y \mathrm{Dag}^{34}$ en artikelserie i fyra delar skriven av Otto Wille Kuusinen. "Om nationalitetsfrågan i Finland"var en översättning av Kuusinens manuskript Kansallisuuskysymyksestä Suomessa, i vilket han teoretiskt utvecklade FKP:s inställning i den finländska nationalitetsfrågan. Kuusinen var vid den här tidpunkten FKP:s obestridliga ledare efter att han året innan gått segrande ur maktkampen med Kullervo Manner, FKP:s ordförande sedan år 1920. Manners öde beseglades i slutet av år 1935 då han dömdes till tio års lägerarbete och uteslöts ur partiet. ${ }^{35}$ Kuusinen förblev en auktoritär gestalt i finländsk kommunism även efter att han begrovs i Kremls mur år 1964, trots att han aldrig återvände till Finland. ${ }^{36}$

Kuusinen kritiserade den "finska chauvinistiska nationalitetsteorin” för att använda begrepp på ett felaktigt och förvirrat sätt. Enligt Kuusinen definierade den finska chauvinistiska nationalitetsteorin, och den finska borgerlighet som anammat denna teori, svenskarna i Finland som tillhörande"den finska nationaliteten". Kuusinen menade att den finska borgerligheten därmed förnekade finlandssvenskarnas nationella existens och påtvingade dem en främmande nationali-

33. Stalin, Marxismen och den nationella frågan, s. 87 .

34. De s.k. kommunistlagarna av I930 förbjöd kommunistisk press i Finland, ett förbud FKP försökte kringgå bland annat genom sitt kontor i Stockholm.

35. Kimmo Rentola, Kenen joukoissa seisot? Suomalainen kommunismi ja sota 1937-1945, Porvoo: WSOY i994, s. 25-30.

36. Tauno Saarela, Finnish Communism Visited, Helsinki: The Finnish Society for Labour History 2015, s. I93-2I4. 
tet. Förnekelsen av att finlandssvenskarna utgjorde en nationalitet underbyggdes genom en avsiktlig ihopblandning av begreppen folk och fosterland med begreppet nationalitet. Kuusinen konstaterade att folk var detsamma som en stats befolkning och att fosterland var detsamma som stat. Det faktum att finlandssvenskar var en del av Finlands befolkning (folk) och stat (fosterland) betydde dock inte "att i Finland icke finnes mer än en nationalitet eller nation". En "härskande majoritetsnation" var, menade Kuusinen, givetvis inte"den enda existerande nationen" i en multinationell stat som Finland. Han påpekade att inte ens de polska majoritetsnationalisterna påstod att Polens folk enbart bestod av polacker eftersom en stor del av befolkningen i landet de facto utgjordes av andra nationaliteter. Kuusinen lyfte också fram Schweiz som exempel: ett folk som huvudsakligen bestod av tre nationaliteter. ${ }^{37}$

Enligt Kuusinen hävdade den "finska chauvinismen" från den ovan beskrivna oriktiga teoretiska utgångspunkten att det endast fanns en svensk "språkgrupp' inom den finska nationen" och att det inte existerade en nationalitetsfråga i Finland utan blott "en 'språkfråga". Att påstå något annat ansåg dessutom dessa chauvinister, som Kuusinen uttrycker det, vara "ingenting mindre än 'fosterlandsförräderi"'. Kuusinen klandrade de finlandssvenskar som i brist på "inre klarhet" i nationalitetsfrågan inte rakt av förkastade den finska chauvinistiska nationalitetsteorin utan i stället vacklade "hit och dit", vilket spelade den finska chauvinismen i händerna. ${ }^{38}$

Enligt Kuusinen hade "kamrat Stalin" gett svar på frågan vad en nation eller nationalitet var"redan I9I3", det vill säga i Marxismen och den nationella frågan. Utgående från Stalins definition av begreppet nation besvarade Kuusinen frågan om Finlands svenska befolkning utgjorde en nationalitet eller nation, vilket enligt honom "var samma sak i detta sammanhang" ${ }^{39}$ :

[F]ör det första, språkgemenskapen är utan vidare klart faktum; för det andra, med undantag av Åland är svenskarnas territoriala gemenskap

37. Otto Wille Kuusinen,"Om Nationalitetsfrågan i Finland. Kampen för den svenska nationalitetens tillvaro i Finland", Ny Dag, I3/5 1935.

38. Ibid.

39. Ibid. 
för handen i tvenne delar av landet, i södra Finlands och Österbottens kusttrakter, även om dessa båda svenska bosättningsområden är åtskilda från varandra; dessutom finnes här och där i städerna i det inre landet spridda svensktalande grupper (dessa är i själva verket bara "språkgrupper”); för det tredje, även ekonomisk gemenskap föreligger på det svenska området, om också landets svenska och finska befolknings ekonomiska liv förstås på många sätt flätas samman med varandra; för det fjärde, $\mathrm{i}$ den svenska kulturen i Finland framträder en egen nationell karaktär, som skiljer sig från den finska nationella karaktären, även om de båda nationella kulturerna rönt mycket inflytande från varandra. Sålunda bör södra Finlands och Österbottens svenska befolkning uppenbarligen anses som en särskild nationalitet, som är nationellt besläktad med Sverges folk, men icke av samma nationalitet. Med Sverges folk har Finlands svenskar, om man undantager ålänningarna, endast språkgemenskap och kulturnärhet, men icke en varaktig kulturgemenskap, för att nu inte ens tala om gemenskap i territorium och ekonomiskt liv. På sin höjd kan man tala om att ålänningarna tillhör samma nation som Sverges folk. ${ }^{40}$

Med tanke på den svenskspråkiga minoritetens ringa befolkningsstorlek (ca ro procent) i förhållande till den finskspråkiga majoriteten (ca 90 procent) vid den här tiden, är det angeläget att fråga sig varför den finlandssvenska nationalitetens ställning och status överhuvudtaget var viktig för kommunistledaren Kuusinen. Förklaringen ligger främst i den leninistisk-stalinistiska revolutionsteorin. Ett av huvuddragen i Kuusinens kritik av samtida socialdemokrater, främst den ledande högersocialdemokraten Väinö Tanner och SDP:s partisekreterare K.H. Wiik ${ }^{41}$, kan summeras med hans anmärkning om att socialdemokraterna underskattade nationalitetsfrågans betydelse för revolutionsfrågan. ${ }^{42}$ Nationalitetsfrågan var inte enbart en fråga om finlandssvenskarnas väl och ve, utan avgörande för den finländska klasskampen som helhet. För Kuusinen var språkstriden ett av den

40. Ibid.

4I. För en diskussion om K.H. Wiiks syn på nationalitetsfrågan i Finland, se Matias Kaihovirta \& Mats Wickström,"Socialdemokratisk och konservativ antifascism i Finland. Karl H.Wiik och Eirik Hornborg inför Lapporörelsen", Historisk Tidskrift for Finland I02, 2017:I, s. 58-60.

42. Otto Wille Kuusinen, Kansallisuuskysymyksestä Suomessa, opublicerat manuskript, s. 44, Otto Wille Kuusinens arkiv, Folkets Arkiv, Helsingfors. 
finländska fascismens främsta redskap för att hetsa de finländska nationaliteterna mot varandra och därmed splittra arbetarklassen. ${ }^{43}$ Finlandssvenskarna fyllde, enligt Kuusinen, samma roll i den finska fascismens agitation som judarna hade i dess tyska dito. ${ }^{44}$

Enligt Kuusinen var det en plikt och ära för den klassmedvetna finska arbetaren att kämpa i främsta ledet för den svenska nationalitetens ställning i Finland. ${ }^{45}$ För Kuusinen var försvaret av den svenska nationen till och med en förutsättning för den finländska klasskampen som sådan; om den finska arbetarklassen inte försvarade finlandssvenskarna skulle den inte heller kunna befria sig själv från borgerlighetens klassförtryck, ett förtryck som förledde den att angripa sina klassbröder. ${ }^{46}$ Förutom denna externa relation, det vill säga att nationella konflikter tenderar att överskugga klasskampen, ansåg Kuusinen också att det fanns ett internt samband mellan klassmedvetenhet och förståelse av den egna nationalitetens intressen. Kuusinen framhöll att den finlandssvenska arbetaren som ännu inte hade vaknat upp till proletär klassmedvetenhet också var likgiltig i kampen för att försvara den egna nationaliteten mot främmande förtryck. ${ }^{47}$ Klassmedvetenhet och medvetenhet i nationalitetsfrågan var två sidor av samma mynt: arbetaren som förstod sin klassposition insåg samtidigt att hen tillhörde en nationalitet som förtrycktes av den ägande klassen, och att den senare endast talade om nationalitetens intressen då dessa sammanföll med det egna intresset.

\section{DFFF OCH FKP SAMT DET SVENSKA I DET EFTERKRIGSTIDA FINLAND}

I sin första kampanj inför ett riksdagsval, år I945, riktade Demokratiska förbundet för Finlands folk (DFFF) följande budskap "Till svenskfolket i Finland":

43. Att nationalitetsstrider avleder arbetarnas uppmärksamhet från klasskampen är också ett centralt tema i Stalins Marxismen och den nationella frågan, se exempelvis s. 87 .

44. Kuusinen, Kansallisuuskysymyksestä Suomessa, s. II-I2.

45. Ibid., s. 21.

46. Ibid.

47. Ibid., s. 27 . 
Den svenska folkminoritetens språkliga rättigheter bör tryggas. Utan demokrati kan svenskfolket ej tillförsäkras språklig rättvisa. Därför bör demokratin i vårt land befästas. Mot fascism och folkförtryck. All fascistisk verksamhet bör förhindras och intrång på de fria medborgerliga rättigheterna får ej ifrågakomma. Äktfinskheten och fascismen har undertryckt det svenska språket. DFFF kämpar för likaberättigande för alla oberoende av språk och ras. ${ }^{48}$

Som citatet visar var försvaret av finlandssvenskarna i detta sammanhang reducerat till en fråga om kampen för minoriteternas (liberala) rättigheter. Den kommunistiska definitionen av finlandssvenskarna som en nationalitet, och det ovillkorliga försvaret av finlandssvenska strävanden efter självbestämmande förekom inte heller i DFFF:s första program år 1949, där finlandssvenskarna även likställdes med "övriga" minoriteter:

Koska kansa, joka sortaa toista kansaa, ei itse voi olla vapaa, on kansallisia vähemmistöjä suojeltava kaikkea kansallisuussortoa vastaan. Itsenäisyysaikana esiintynyt pyrkimys riistää ruotsalaiselta kansanosalta sen oikeuksia on epädemokraattisena tuomittava. SKDL puolustaa tinkimättä ruotsinkielisen vähemmistön niin kuin muidenkin vähemmistöjen kansalais- ja perustuslaillisia oikeuksia. ${ }^{49}$

DFFF:s programförklaringar mot förtryck och för rättigheter var alltså allmänt hållna och universalistiska. Det här hindrade dock inte de finlandssvenska folkdemokraterna från att på minoritetsnationalistisksocialistisk grund och i förhållande till den svenska befolkningen i Finland driva den leninistisk-stalinistiska linje som FKP utstakat

48. Demokratiska förbundet för Finlands folk, Till svenskfolket i Finland, Helsingfors: DFFF r945. Fetstil i original.

49. "Eftersom ett folk som förtrycker ett annat folk inte självt kan vara fritt måste nationella minoriteter försvaras mot allt nationalitetsförtryck. Den strävan att frånta den svenska folkgruppen dess rättigheter som förekommit under självständighetstiden måste som odemokratisk fördömas. DFFF försvarar obetingat såväl den svenska minoritetens som andra minoriteters medborgerliga och grundlagsenliga rättigheter." [Svensk översättning: MJ \& MW]. Suomen Kansan Demokraattinen Liitto,"Suomen Kansan Demokraattisen Liiton Ohjelma" (1949), http://www.fsd. uta.fi/pohtiva/ohjelmalistat/SKDL/62I (hämtad I8/Io 20I7). 
under mellankrigstiden. Detta skedde med fortsatt stöd av partiet. När FKP efter tio års uppehåll höll sitt sjunde partimöte i Helsingfors i oktober år 1945, FKP:s första partimöte i Finland, antog de nu öppet och lagligt verkande kommunisterna även en resolution i den finländska nationalitetsfrågan.

I samklang med både Stalins och Kuusinens skrifter motsatte sig FKP all form av kulturautonomi för finlandssvenskarna. Med kulturautonomi avsåg partiet reaktionära svensk-borgerliga krav på autonomi för de svenskspråkiga områdena. Dessa krav syftade, enligt FKP, enbart till att tillgodose finlandssvenskarnas språkliga rättigheter och tog inte hänsyn till det faktum att"de sociala missförhållandena inte i grunden är av språklig art". ${ }^{50}$ "Utsugningsförhållandet" var, som FKP såg det, detsamma för de två språkgrupperna. Man menade också att de grundläggande problemen beträffande den svenskspråkiga befolkningens "existensmöjligheter" inte skulle lösas genom en förment lösning av språkfrågan och en kulturautonomi ledd av reaktionärer ("näringslivets ledare, präster och lärare"). ${ }^{51}$ Detta framför allt på grund av att en avgörande skillnad rådde mellan den svensk- och finskspråkiga befolkningen: den finskspråkiga var "kraftigare och klarare uppdelad enligt klassgränserna" eftersom"de reaktionära kretsarna" med hjälp av språkfrågan kunnat avskilja de svenska kamraterna från de finska. ${ }^{52}$ En borgerlig, kulturautonom lösning skulle endast ge de reaktionära ännu mer makt i de svenskspråkiga kommunerna och det finlandssvenska kulturlivet skulle i sin helhet "underkastas den reaktionära makten". Den rätta lösningen på finlandssvenskarnas sociala och nationella problem var inte reaktionär kulturautonomi utan "en demokratiskt förverkligad nationell självbestämningsrätt". ${ }^{53}$

För att uppnå detta demokratiska minoritetsnationella självbestämmande måste först och främst "demokratin föras till seger överallt i vårt land"54, det vill säga Folkrepubliken Finland måste förverkligas.

50. Finlands kommunistiska parti, Det nuvarande läget och de förestående uppgifterna. FKP:s VII partimötes resolution: Nationalitetsfrågan i Finland, Helsingfors: FKP I945, s. I8.

51. Finlands kommunistiska parti, Det nuvarande läget, s. I9.

52. Ibid., s. I8.

53. Ibid., s. I9.

54. Ibid. 
Till skillnad från FKP:s mellankrigstida deklarationer, som villkorslöst propagerade för finlandssvenskarnas och ålänningarnas rätt till självbestämmande för sina respektive territorier, fördömde partiet nu all icke-demokratisk eller reaktionär strävan efter självbestämmande som skadlig separatism. Ett från Finland avskilt Åland skulle utgöra ett farligt fascistiskt näste, och hota såväl demokratin i Finland som freden i Nordeuropa. Borgerligt ledd finlandssvensk separatism på fastlandet skulle likaså enbart försvåra livet för merparten av den svenskspråkiga befolkningen. ${ }^{55}$

FKP fortsatte ändå att hålla fast vid principen om nationellt självbestämmande. Som en del av den genomgripande demokratiseringen av Finland skulle nationalitetsfrågan också få en slutlig lösning genom följande åtgärder: i södra Finland och i Österbotten skulle regional autonomi för den svenska befolkningen etableras för att trygga den svenska minoritetsnationalitetens rättigheter. För att man skulle upprätthålla förbindelser mellan staten och de autonoma regionerna samt Åland, skulle finlandssvenskarna erhålla särskild representation i parlamentet. Därutöver skulle den generella demokratiska omvälvningen av samhällslivet också säkerställa den svenskspråkiga befolkningens nationella och demokratiska rättigheter. Utsikterna att genomföra denna progressiva lösning av nationalitetsfrågan var beroende av"den finländska demokratins slutliga seger" ${ }^{56}$ Med andra ord var det ytterst sett enbart genom en socialistisk revolution som ett självbestämmande Svenskfinland kunde skapas - utan detta villkor skulle alla former av borgerlig autonomi enbart resultera i en splittrad finländsk arbetarklass.

Partimötets ställningstaganden visar att de finlandssvenska folkdemokraterna gavs politisk fullmakt att följa upp den bolsjevistiska teoribildningen i nationalitetsfrågan i sin verksamhet. Socialistisk minoritetsnationalism blev även ett av huvuddragen i DFFF:s svenska opinionsbildning under de första efterkrigsåren. I förhållande till Svenska folkpartiet (SFP) och Finlands Svenska Arbetarförbund (FSA) försökte DFFF påvisa att folkdemokraterna, till skillnad från

55. Suomen kommunistinen puolue, SKP:n VII puoluekokouksen selostuksia I: SKP:n valistustyö ja julkaisutoiminta. Vähemmistökansallisuuskysymyksistä Suomessa, Helsinki: SKP:n valistusjaosto I945, s. 43-44.

56. Finlands kommunistiska parti, Det nuvarande läget, s. 24. 
SFP, som när det kom till kritan prioriterade kapitalets intressen framom den svenska nationalitetens, och FSA, som inte ens insåg frågans avgörande betydelse, var finlandssvenskarnas"säkraste värn" ${ }^{\text {"57 }}$.

\section{FINLANDSSVENSKARNA SOM OFÖRLÖST NATIONALITET}

I det partiprogram som Svenska folkpartiet (SFP) antog år 1937 framhävde man att partiets syfte var"att på fosterländsk grund sammansluta den svenska nationaliteten i Finland för att värna dess ställning och rätt i fäderneslandet”. ${ }^{58}$ Alla hänvisningar till svensk nationalitet $\mathrm{i}$ Finland ströks emellertid ur partiprogrammet år 1940 för att bevara den språkfred som uppnåtts under vinterkriget. Nationalitetsbegreppet återkom inte heller senare i SFP:s program och partiet avstod även från att använda det offentligt från och med år $1940 .{ }^{59}$ Samtidigt som SFP officiellt tonade ner sin minoritetsnationalism, underströk Demokratiska förbundet för Finlands folks (DFFF:s) finlandssvenska representanter att det svenska i Finland inte enbart var en språkfråga utan att finlandssvenskarna fortsättningsvis utgjorde en nationalitet med därtill hörande anspråk och rättigheter.

Ett typiskt exempel på detta var den folkdemokratiska riksdagsmannen Gösta Rosenbergs svenska dagen-tal i Vasa år 1950, där han redan $\mathrm{i}$ inledningen angav den minoritetsnationella tonen:

Vi är församlade i afton här i Vasa för att gemensamt fira svenska dagen. Det synes mig därför angeläget att öppet och utan omsvep få beröra några frågor av betydelse för oss alla, som har svenska till modersmål, som är medvetna om att vi tillhör Finlands svenska folkstam, den finlandssvenska nationaliteten. ${ }^{60}$

57. Propagandaslogan från 1947. Citerad i Ett förbund för samarbete och demokrati: Om DFFF:s utveckling, karaktär och uppgifter, Helsingfors: DFFF i978, s. Io.

58. Svenska folkpartiet, Program för Svenska Folkpartiet (1937), http://www.fsd.uta.fi/ pohtiva/ohjelmalistat/SFP/565 (hämtad 25/10 2017).

59. Meinander, Nationalstaten, s. 3I.

6o. Gösta Rosenberg,"Vi svenskar bör arbeta hand i hand med de icke-nationalistiska och demokratiska krafterna på finskt håll”, $N y$ Tid 8/II I950. 
Att Svenska Finlands Folkting hade övertagit ansvaret för arrangemangen kring svenska dagen av SFP hade öppnat upp firandet även för de finlandssvenska arbetarna. Enligt Rosenberg hade den finlandssvenska vänstern tagit avstånd från svenska dagen-firandet på grund av dagens partipolitiska karaktär och dess utländska ursprung. Han karaktäriserade svenska dagen som "ett led i en allsvensk samling, som i denna form måste vara främmande för finlandssvenskarna, som ingalunda är någon folkspillra, utan bildar en nationalitet med en egenartad kultur" ${ }^{61}$ Rosenberg syftade på den allsvenska rörelsen, en pan-nationalistisk rörelse med slagordet "Svenskar i all världen förenen eder!". I Finland var rörelsen förenad med östsvenskheten, en idéströmning och politisk inriktning som betonade den svenskspråkiga befolkningen i Finlands (östsvenskarnas) nationella samhörighet med Sverige och riks- eller västsvenskarna där. ${ }^{62}$ Rosenberg gjorde en ideologisk markering mot all- och östsvenskhet på basis av den kommunistiska nationalitetsteorin: finlandssvenskarna var inte, som Kuusinen visat med utgångspunkt i Stalins teori, av samma nationalitet som svenskarna i Sverige och utgjorde därmed inte heller någon borttynande svensk rest i förskingring utan en egen nationalitet.

Rosenberg betonade vikten av allfinlandssvenskt samarbete över partigränserna i de frågor som berörde "den finlandssvenska nationalitetens livsintresse", men framhöll samtidigt att en nationalitet blott kunde "blomstra" i ett samhälle som inte var en "skendemokrati". Rosenberg påminde även åhörarna om hur illa det var ställt med såväl den finländska demokratin som den "finlandssvenska fronten" under I930-talet, då "de finlandssvenska storfinanskretsarna aktivt medverkade i den fascistiska rörelsen". Den "passiva och ryggradslösa inställning till den äktfinska nationalismen", en inställning som den finlandssvenska storfinansen uppvisade under Lappoåren, visade enligt Rosenberg att dessa kapitalister "medvetet" stödde förtrycket av finlandssvenskar och splittrade deras främsta värn, "den nationella finlandssvenska fronten". Det fanns dessutom fortfarande finlands-

6I. Rosenberg, "Vi svenskar".

62. Bengt Kummel, Svenskar i all världen förenen eder! Vilhelm Lundström och den allsvenska rörelsen, Åbo: Åbo Akademis förlag I994, s. I64-I65. 
svenskar, förklarade Rosenberg, som "vore beredda att sälja sin egen nationalitet för snöd vinnings skull". ${ }^{63}$

Finlandssvenskarnas framtid var framför allt beroende av den så kallade demokratiseringen av samhället, det vill säga införandet av ett socialistiskt samhällssystem. Som hoppingivande exempel på vilka "rika framtidsutsikter" en demokratisering skulle föra med sig för finlandssvenskarna gav Rosenberg"vårt östra grannland, där den rådande samhällsformen bygger på den konsekventa demokratins grundval". I Sovjetunionen hade "genomförandet av den socialistiska principen om nationernas likaberättigande på alla områden” enligt Rosenberg "lett till att de olika nationella kulturerna blomstrat upp i hittills oanad utsträckning”. Utan att nämna Stalin, antagligen med hänsyn till den borgerliga publiken i Vasa stadshus ${ }^{64}$, presenterade sedan Rosenberg sitt svar på nationalitetsfrågan genom att parafrasera och citera från Marxismen och den nationella frägan:

[E]n oundgänglig punkt vid lösandet av denna fråga är genomförandet av absolut nationellt likaberättigande samt en på grundval av landets fullständiga demokratisering utfärdad allmän statlig lag, som utan undantag förbjuder alla former av nationella privilegier och varje intrång på eller inskränkning av de nationella minoriteternas rättigheter. ${ }^{65}$

Denna lösning krävde enligt Rosenberg att "vi finlandssvenskar" arbetade "hand i hand" med"de icke-nationalistiska och demokratiska krafterna inom den finska befolkningen" eftersom finlandssvenskarna var beroende av dem "om vi verkligen vill tillvarata alla möjligheter att vidare utveckla vårt kulturella och nationella liv på vårt eget språk”.

Den kommunistiska nationalitetsteorin, såsom den hade formulerats av Stalin år I9I3 och tillämpats på finlandssvenskarna av Kuusinen år 1935, var också central för de finlandssvenska folkdemokraternas förfäktande av nationalitetsfrågan inom Finlands kommunistiska parti. På de diskussionsdagar som FKP:s partistyrelse samlats till i mitten av november 1950 höll partifunktionären Mikael Romberg

63. Rosenberg, "Vi svenskar".

64. "Svenska dagen i Vasa", Vasabladet 7/II I950.

65. Rosenberg,"Vi svenskar". 
ett anförande om "Finlandssvenskarnas nationella problem", där han förutom att redogöra för den kommunistiska nationalitetsteorin och svenskhetens historia i Finland även prövade om Kuusinens slutsatser fortfarande höll streck.

Romberg tillstod att det svenska bosättningsområdet i södra Finland, som Kuusinen år 1935 betraktat som ett av finlandssvenskarnas två nationella territorier, "splittrats sedan östra Nyland genom en omfattande finsk inflyttning till trakterna vid huvudbanan till Helsingfors avskilts från sydvästkusten”. Detta betydde dock enligt Romberg inte att de principiella kriterierna för en territoriell gemenskap inte längre uppfylldes "eftersom det fortfarande bor rikligt med svenskar på de förfinskade områdena”. Stalins fjärde kriterium för nationskap, den gemensamma kulturen, var också problematisk på grund av "de bojor, i vilka kapitalismen och i detta särskilda fall kulturdiktatorn Amos Anderson med bergsrådsvänner binder de finlandssvenska kulturutövarna”. Den finlandssvenska kulturen var trots det fortfarande livskraftig, vilket innebar att den uppfyllde det fjärde kriteriet, och genom att frigöra den från kapitalismen skulle den "andas fritt". ${ }^{66}$

Rombergs granskning av Kuusinens bedömning utmynnade i slutsatsen att det som "av Kuusinen bevisats" fortfarande var giltigt: finlandssvenskarna utgjorde en nationalitet. Därmed kunde Romberg också konkludera att Stalins svar på den nationella frågan från år I9I3 fortfarande gick att tillämpa på finlandssvenskarna och kraftfullt avsluta sitt anförande med Stalins egna ord om de nationella minoriteternas rättigheter. ${ }^{67}$ Eftersom Romberg i första hand riktade sin utläggning till partistyrelsen var ett åberopande av Stalin en styrka.

Det leninistiskt-stalinistiskt härledda begreppsliggörandet av finlandssvenskarna som en nationalitet lyftes också fram i de finlandssvenska folkdemokraternas valpropaganda. I pamfletten I finlandssvenskarnas intresse som utgavs inför riksdagsvalet I95I framförde folkdemokraterna att endast DFFF till fullo försvarat finlandssvenskarnas intressen under mandatperioden. Folkdemokraterna hänvisade till det borgerliga Svenska befolkningsförbundets dystra prognoser över finlandssvenskarnas demografiska utveckling, och konstaterade att "de

66. Mikael Romberg, "Finlandssvenskarnas nationella problem", $N y$ Tid I3/3 I95I. 67. Mikael Romberg, "Finlandssvenskarnas nationella problem", $N y$ Tid I6/3 I95I. 
finlandssvenska borgarna" varken kunde eller ville understödja de ekonomiska och sociala reformer"som skulle trygga finlandssvenskarnas nationella framtid". ${ }^{68}$ Det enda SFP kunde erbjuda var moralkakor om lyckan med flera barn och barnbidrag, vilket endast skulle leda till "mera försakelse" och "inte trygga finlandssvenskarnas framtid som nationalitet". ${ }^{69}$ Det som behövdes för att förbättra finlandssvenskarnas levnadsvillkor och förhindra att de svenskspråkiga i Finland förtvinade som nationalitet var bland annat omfördelning av jorden, nationalisering av de största industrikoncernerna, högre löner till arbetarna, skattelindringar och statlig bostadsproduktion. ${ }^{70}$

\section{Med eller Utan Stalin för Det SVEnSka i Finland}

Den finlandssvenska folkdemokratins leninistiskt-stalinistiskt underbyggda kamp för den finlandssvenska nationaliteten avtog dock märkbart efter riksdagsvalet i juli i951. Den förblev ändå en del av de finlandssvenska folkdemokraternas ideologiska repertoar och återupplivades delvis av de unga teorimedvetna finlandssvenska minoritetskommunisterna i början av 1970-talet. ${ }^{71}$ Att den minoritetsnationella profilen försvagades från och med sommaren I95I hängde ihop med att FKP samma höst, i samband med en omstrukturering av partiorganisationen, fattade beslut om att lägga ner (enspråkigt) svenska partiavdelningar samt partiets svenska sektion. Nerläggningsbeslutet föredrogs post factum av FKP:s Martin Backman på partiets nionde representantmöte i Helsingfors den 4 november 195 I. $^{72}$

Backman hävdade att en uppdelning av partiets basorganisationer på nationell grund var ett inbyggt fel som i praktiken lett till att FKP:s svenska sektion självständigt styrt de svenskspråkiga partiavdelningarna och drivit en egen politisk linje. Denna linje, med sin tyngdpunkt på nationalitetsfrågan, hade dessutom varit föranledd av

68. Demokratiska förbundet för Finlands folk, I Finlandssvenskarnas intresse, Helsingfors: DFFF I95I, s. I3.

69. Ibid., s. I4.

70. Ibid., s. I5

7I. Se exempelvis Leif Salmén, "Kansallisuuskysymys", Soihtu 37, I973:5, s. I7-53.

72. Martin Backman, "Puheenvuoro 37", I039:27, Edustajakokouksen pöytäkirjat, Suomen kommunistinen puolue I944-I990, Folkets Arkiv, Helsingfors. 
bristfällig teorikunskap och rädsla för angrepp från SFP. ${ }^{73}$ Backman motiverade teoretiskt avvecklingen genom att citera Stalin, som för övrigt valdes in i representantmötets hederspresidium som första namn (Kuusinen kom in som andra före Mao) ${ }^{74}$ :

Venäjän kaikkien kansallisuuksien työläisten yhdistäminen eri paikkakunnilla yhtenäisiksi ja ehjiksi kollektiiveiksi, tällaisten kollektiivien yhdistäminen yhtenäiseksi puolueeksi - sellainen on tehtävä. ${ }^{75}$

Citatet var taget ur samma källa som hans finlandssvenska partikamrater begagnat sig av: Marxismen och den nationella frägan. ${ }^{76}$ Backman följde upp citatet med att åberopa Stalins och det ryska bolsjevikpartiets framgångsrika uppbyggnad av socialism:

Se on kansakuntien yhtenäisen järjestömuodon avulla vapauttanut työväenluokan sorrosta ja riistosta. Bolshevikkipuolueen järjestömuodoilla on tässä ollut ratkaiseva merkitys. ${ }^{77}$

I den föredömligt enhetliga bolsjevistiska partiorganisationsformen som FKP ämnade efterfölja fanns det enligt Backman (och genom honom partiledningen), lika lite plats för separatistisk svenskhet som det funnits för bundism i bolsjevismen. Backman var likväl mån om att avslutningsvis framhålla att organisationsreformen inte var ett dråpslag mot den svenska nationaliteten i Finland utan en mobilisering av den, för att uppnå det väsentliga, nämligen klasskampen:

73. Ibid., s. 3 .

74. "Kunniapuhemiehistön valinta", I039:27, Edustajakokouksen pöytäkirjat, s. I, Suomen kommunistinen puolue 1944-I990, Folkets Arkiv, Helsingfors.

75. "Lokal sammanslutning av arbetarna tillhörande alla nationaliteter i Ryssland till enhetliga och slutna kollektiv, dessa kollektivs sammanslutning till ett enhetligt parti - det är uppgiften." Backman, "Puheenvuoro 37", s. 2.

76. S. 90 i den svenska upplagan från 1950.

77. "Det [partiet] har befriat arbetarklassen från förtryck och utsugning med hjälp av en enhetlig organisationsform för nationerna. Bolsjevikpartiets organisationsformer har här haft avgörande betydelse." [Svensk översättning: MJ]. Backman, "Puheenvuoro 37", s. 2. 
Tapahtunut järjestely, ei merkitse siis maamme ruotsinkielisen kansallisuuden uhraamista, vaan sen johtamista taisteluun puolueemme johdolla rauhan, leivän, maan - sosialismin puolesta. ${ }^{78}$

Avskaffandet av de svenskspråkiga organisationerna och de svårigheter som detta ledde till för såväl de svenskspråkiga partimedlemmarna som funktionärerna beträffande möjligheten att ta del av verksamheten i partiavdelningarna och koordinera det politiska arbetet på svenska blev föremål för diskussion och kritik först efter Chrusjtjovs tal "Om personkulten och dess konsekvenser" i februari 1956. I talet kritiserade den nya ledaren Stalin och den despotiska stalinismen, särskilt utrensningarna av partimedlemmar och ideologiska avvikelser. Stalins död år I953 och den därpå följande avstaliniseringen under Chrusjtjov undergrävde Stalins auktoritet som ideolog, vilket exempelvis Romberg utnyttjade i polemik mot Backmans och partiets stalinistiska legitimering av nedläggningen av de svenskspråkiga organisationerna i maj $1956 .^{79}$

Samtidigt minskade förstås också den politiska tyngden i en hänvisning till den store ledaren Stalin då man ville påvisa att finlandssvenskarna var en nationalitet, men denna kategorisering var ändå etablerad inom FKP och ifrågasattes inte i samband med upplösandet av det svenskspråkiga organisationsfältet. Förbudet mot svenskspråkiga partiavdelningar hävdes mot slutet av I950-talet samtidigt som FKP:s svenska sektion delvis återuppstod i form av ett återkommande svenskt rådplägningsmöte från och med år 1956. Sektionen återetablerades formellt vid mitten av ig6o-talet. Inom den finlandssvenska folkdemokratin, vars formellt DFFF-ledda organ och institutioner fortsatte sin verksamhet utan avbrott, förblev övertygelsen om finlandssvenskhetens etniska (nationella) egenvärde framträdande, likaså övertygelsen om folkdemokratins roll som dess förlösare och framtidshopp. Till syvende och sist var Stalins lärosatser inte utslagsgivande för klasskampen på

78. "Den genomförda omorganiseringen innebär således inte att den svenskspråkiga nationaliteten $i$ vårt land offras, utan att den styrs in i en av vårt parti ledd kamp för fred, bröd, land - för socialism." [Svensk översättning: MJ \& MW]. Ibid., s. 4.

79. Mikael Romberg, "Bilaga 2" [Protokoll fört vid svenska funktionärernas rådplägningsmöte 27/5 1956], 8026:3, Pöytäkirjat, Suomen kommunistinen puolue I944-I990/Ruotsalaisjaosto, Folkets Arkiv, Helsingfors. 
svenska, vars bas, den förtryckta majoriteten av det finlandssvenska folket eller den finlandssvenska nationaliteten, fortsättningsvis var i behov av befrielse.

I vår undersökning har vi utmejslat de idéhistoriska ramarna för de folkdemokratiska visionerna för finlandssvenskarna under en period när Folkrepubliken Finland fortfarande var ett möjligt framtidsscenario. I en sådan framtid var finlandssvenskarnas öden onekligen sammanvävda med den leninistisk-stalinistiska nationalitetsteorin - vare sig denna tolkades som att finlandssvenska särlösningar skulle befrämjas eller motarbetas. Ovissheten hör till den kontrafaktiska hypotesens natur, så ingen kan förstås påstå sig veta hur det hade gått om kommunismen kommit till makten i efterkrigstidens Finland. Bara utgångspunkten kan vi veta med säkerhet, nämligen att framtiden i detta öppna fall ${ }^{80}$ hade utformats i enlighet med de segerrika kommunisternas tankevärld.

8o. För andra öppna fall i Finlands historia, se Öppet fall. Finlands historia som möjligheter och alternativ ${ }_{14}{ }^{2} 7^{-2 O I}$, Nils Erik Villstrand \& Petri Karonen (red.), Helsingfors: Svenska litteratursällskapet i Finland 20I7. 